\title{
Shell remains provide clues to historical distribution and abundance patterns in a large seagrass-associated gastropod (Strombus gigas)
}

\author{
Allan W. Stoner, Melody Ray \\ Caribbean Marine Research Center, 805 E. 46th Place, Vero Beach, Florida 32963, USA
}

\begin{abstract}
Positive correlation between the number of shells or skeletal elements of a species preserved in the sedimentary record and the abundance and distribution of the once-living population can be an important assumption in paleoecological analysis. The assumption was tested for the large gastropod Strombus gigas (queen conch) in and around 2 nursery grounds in the central Bahamas. Concentrations of shell fragments on the surface of the sediment measured in 1990 were closely correlated $(r=0.998$ and 0.928$)$ with mean live conch abundance monitored regularly at 13 stations during the 2 previous years. Projections from field experiments on shell decomposition rates indicated that the shell remains of $S$. gigas last for at least a decade on the sediment surface. The direct relationship between shell remains and living populations integrated over time permits interpretation of historic changes in populations. Furthermore, time-averaging qualities of the death assemblages provide an integration of distribution and abundance patterns on an ecological time scale useful in learning the relationships between the environment, the species and its management.
\end{abstract}

KEY WORDS: Death assemblage Gastropod Paleoecology $\cdot$ Strombus gıgas - Taphonomy

\section{INTRODUCTION}

Mollusc shells and skeletal elements of other marine invertebrates are used routinely in studies of anthropology (Shawcross 1967, Meehan 1982, Keegan 1984, 1986, 1992), paleontology (Kidwell 1991, Clarkson 1993), and paleoecology and evolution (Valentine 1973, Boucot 1981, Woodin 1983, Hallam 1984, Vermeij 1987. Greenstein 1992). Immediately after death, however, organisms are affected by taphonomic processes, i.e. physical, chemical, and biological processes such as transport, maceration, dissolution, and bioturbation that deposit, preserve, accumulate, and destroy the remains and their patterns of horizontal and vertical distribution (see Kidwell 1991 for a recent review). Positive correlation between the number of shells or skeletal elements of a species preserved in the sedimentary record and the abundance and distribution of the once-ilving population can be an important assumption in paleoecological analysis. Lack of data on this relationship has caused great controversy, for example, in the interpretation of historic records for the coral-consuming crown-of-thorns seastar Acanthaster planci. Whether or not there is fossil evidence for recurring outbreaks has been debated (Henderson \& Walbran 1992, Keesing et al. 1992, Pandolfi 1992), and the answers have important management implications.

Faunal death assemblages normally represent an accumulation of individuals that did not live simultaneously but are preserved in the same sedimentary strata because of bioturbation and other disturbances. As a result of this 'time-averaging' (Walker \& Bambach 1971, Powell et al. 1989) of chronological sequences, diversity and abundance of species may appear higher in the death assemblages than in the living population at a particular point in time, and true chronological patterns can be difficult to ascertain (Van Valen 1964, Johnson 1965, Peterson 1977, Kidwell \& Bosence 1991). Nevertheless, such integrated records can be useful to marine ecologists and conservation biologists in showing long-term and large-scale patterns. The 
skeletal remains of molluscs and other benthic invertebrates reflected very well the living communities associated with major physical environments in both temperate and tropical lagoons on the Pacific coast of North America (Warme 1971, Warme et al. 1976). Warme and others (Kidwell \& Bosence 1991) concluded that shell remains often map communities and habitat types better than any single census of the living community.

The population abundance of many marine species fluctuates over time and space. Such fluctuations are well documented for large molluscs that represent important marine fisheries, including scallops (Dickie 1955, Caddy 1979, Aoyama 1989), abalone (Tegner 1989), and queen conch (Berg \& Olsen 1989, Glazer \& Berg 1994). The practical method commonly used to detect population fluctuations in aggregated animals over time involves frequent, often expensive, surveys of population size and distribution. Each survey, however, represents only a single point in a constantly changing system. In this study, we provide empirical evidence for a direct relationship between shell remains of the mesogastropod Strombus gigas (queen conch) and living distribution patterns of the species at 2 sites in the Bahamas. Although the relationship between abundance patterns of living and dead organisms can be complex (Johnson 1965, Peterson 1975), our data provide support for the validity of interpreting distribution patterns based on evidence from the sedimentary record. Furthermore, the spatial-time-averaging (sensu Powell et al. 1989) provided in the 2-dimensional record of the death assemblage is a useful tool. for assessing recent distributional history and predicting critical habitats for species management or restoration.

\section{METHODS}

The Exuma Cays island chain in the central Bahamas (Fig. 1) lies between the Exuma Sound and the shallow Great Bahama Bank. Exchange between these 2 water bodies occurs through numerous tidal inlets creating tidal flow fields. Most adult conch (and reproduction) occur in shelf waters in the Sound (Stoner \& Schwarte 1994), but conch larvae are carried onto the Great Bahama Bank where they settle and metamorphose in specific shallow seagrass areas along the primary tidal pathways (Davis \& Stoner 1994, Stoner \& Davis in press) that provide nursery habitat for juveniles year after year (Wicklund et al. 1991, Stoner et al. 1994 , 1996). Juveniles migrate with age to the offshore spawning sites, and adults are relatively rare on the Bank (3 adults ha ${ }^{-1}$ i Stoner \& Schwarte 1994). As an adult, the queen conch is one of the largest and most abundant gastropods inhabiting the tropical Atlantic region (Randall 1964), and it has been an important human food resource for thousands of years (Brownell \& Stevely 1981, Keegan 1992).

As part of a 7 yr analysis of queen conch population dynamics near Lee Stocking Island, in the southern Exuma Cays, annual surveys of conch density have been made within juvenile aggregations since 1988 (Stoner \& Waite 1990, Stoner et al. 1996). Two of these nursery areas were selected for this study, Shark Rock (SR) and Children's Bay Cay (CBC) (Fig. 1). Most of the flood tidal water that enters the bank north of Lee Stocking Island passes along the deepest channel toward SR and over the largest nursery ground. A secondary flow travels east then south toward a smaller nursery area. SR stations were selected to represent the long dimension of the largest nursery (northeastsouthwest; Stns SR-1 to SR-7), and to include stations distinctly outside the primary tidal flow field and juvenile population (Stns SR-8 and SR-9). Stns SR-1 and SR-7 were just outside the boundaries of the large aggregation as established for the period from 1988 to 1992 (Stoner \& Ray 1993, Stoner et al. 1994). During the same period, in the tidal flow field south of $\mathrm{CBC}$, the most persistent aggregation and highest densities of queen conch juveniles occurred in a circular aggregation immediately west of the Cay. Stn CBC-1 was selected to represent the high-density center $(>1.0$ conch $\mathrm{m}^{-2}$ ) of the aggregation, while the other 3 were located in lower density areas near the aggregation peripheries (Fig. 1). Because of heavy fishing and ontogenetic migration of conch, adults were always rare in the study sites. At all stations the bottom presented a hard surface of medium sand with a moderate cover of seagrass Thalassia testudinum $\left(<700\right.$ shoots $\left.\mathrm{m}^{-2}\right)$ and detritus. This is typical of the primary conch habitat in the Bahamas (Stoner et al. 1994, 1996).

Surveys for living conch were made at the 2 study sites over a period of 2 yr between July 1988 and May 1990. In 1988 and 1989, the numbers of juvenile conch were counted in 5 haphazardly placed circles (area $=$ $20 \mathrm{~m}^{2}$ ), while 3 larger circles (area $=50 \mathrm{~m}^{2}$ ) were used in 1990. All stations were surveyed in July 1988, February, May, August, and November 1989, and February and May 1990, with a few exceptions. SR-9, CBC-2, $\mathrm{CBC}-3$, and $\mathrm{CBC}-4$ were not surveyed in May and November 1989. CBC-1 was surveyed every month in 1989. Mean conch densities for each station during each survey were calculated from the replicate circles. The values reported in Table 1 for each station represent the mean of average densities from all of the surveys conducted over the 2 yr study period.

Conch shell fragment data were collected at the time of the last live conch survey in May 1990, using the same $50 \mathrm{~m}^{2}$ plots. The sediment surface in each plot 
Fig. 1. Map of the study site showing the location of the 13 stations surveyed for the density of living queen conch Strombus gigas and shell fragments. Solid lines: peripheries of primary juvenile conch aggregations near Lee Stocking Island, Bahamas, between 1988 and 1992 (Stoner et al. 1996). Arrows: general direction of flood tide currents

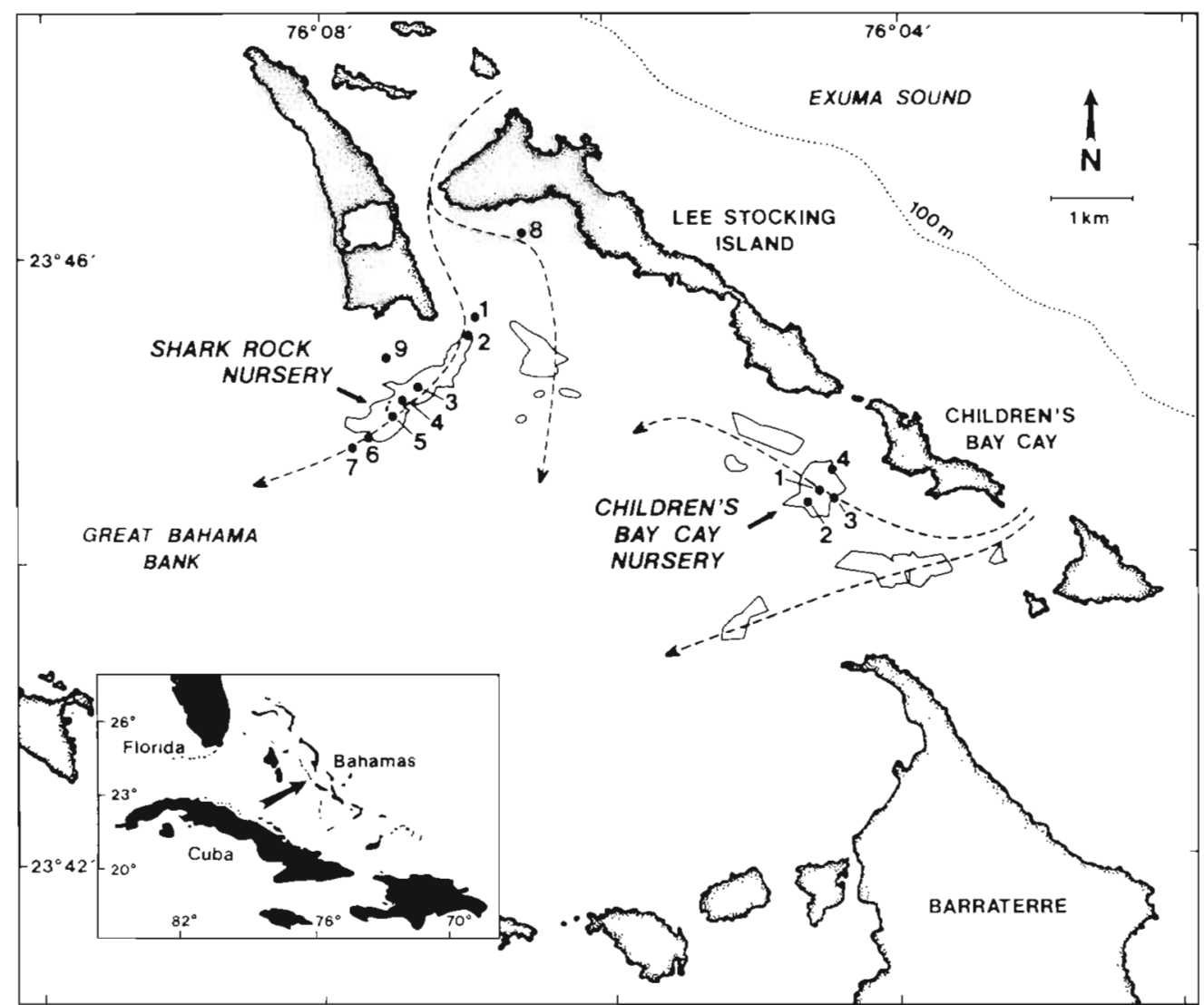

was carefully searched for the remains of queen conch shells. The majority of these were the remains of whole shells; however, shell pieces larger than $\sim 1 \mathrm{~cm}$ in maximum dimension were also counted. Shell remains were visually obvious on the firm white sand or easily detected by touch under detritus. The shells were distinguishable as those of Strombus gigas either by shape or color. The only other large gastropods at the study sites are Fasciolaria tulipa (tulip snail) and Charonia variegata (Triton's trumpet); these are relatively rare compared to queen conch and would not be easily confused with remains of queen conch. Inclusion of shell fragments in the total count potentially overestimates the number of conch represented in the death assemblage; however, near Lee Stocking Island most conch larger than $20 \mathrm{~mm}$ are killed by predators that do not crush the shells, and they are usually left largely intact at death (Ray et al. 1994). The remains of adult conch were very rare (total $=\sim 10$ ) and not included in the density of shell fragments.

Shells from recently killed conch were placed in the field to determine rates of shell decomposition. The experimental shells, free of soft tissue and epibiota, were weighed, measured for maximum shell length (spire to siphonal canal), marked with uniquely numbered, vinyl spaghetti tags, and placed in enclosures at
Stns SR-4 and CBC-1. Round enclosures for the shells (diameter $=1.0 \mathrm{~m}$, height $=30 \mathrm{~cm}$ ) were constructed of vinyl-coated wire $(2.5 \times 5 \mathrm{~cm}$ mesh) secured to vertical reinforcement bars driven into the sediment, and covered with white nylon netting material (mesh = $2.5 \mathrm{~cm}$ ). The enclosures helped prevent shell dispersal by hermit crabs and physical processes. Conch shells in the following length size classes were put in the CBC cage on 13 May 1992: 91-100 mm (53-102 $\mathrm{g}, \mathrm{n}=$ 20) and 67-77 $\mathrm{mm}(23-33 \mathrm{~g}, \mathrm{n}=5)$. On the next day, shells in the following length size classes were put in the SR cage: $90-98 \mathrm{~mm}(56-87 \mathrm{~g}, \mathrm{n}=20), 68-80 \mathrm{~mm}$ $(23-39 \mathrm{~g}, \mathrm{n}=5)$, and $129 \mathrm{~mm}(176 \mathrm{~g}, \mathrm{n}=1)$. These sizes are typical of conch 6 to $18 \mathrm{mo}$ old.

The shells were recovered from cages at both sites on 16 June 1992, 11 September 1992, and 15 May 1993, reweighed, and replaced within $10 \mathrm{~d}$. At CBC, final recovery was made on 30 August 1995, and at SR, on 27 May 1994. Final recovery at SR was earlier because the cage was damaged, and all of the shells were lost after the 1994 recovery. Because our purpose was to determine the rate of loss in actual shell material, recovered shells were scrubbed to remove sediment, algae, encrusting animals, and hermit crabs which were frequent inhabitants. The shells were dried and weighed. Shell loss related to the cleaning process was considered 
to be negligible as no hard scraping was applied, and the shell surfaces appeared to be little weakened after 2 yr of exposure. In a few cases, hermit crabs could not be completely extracted. These shells were excluded from analysis. Shell decomposition was measured in terms of percentage of total weight lost and weight loss per day. To test for site differences in shell decomposition and for annual variation, results were compared statistically using Student's t-test when variances were homogeneous (Cochran's test, p > 0.05), and the nonparametric Mann-Whitney $U$-test when variances were heterogeneous (Cochran's test, $p<0.05$ ).

\section{RESULTS}

Mean densities of juvenile queen conch in the 2 survey areas ranged from 0 to 1.53 conch $\mathrm{m}^{-2}$ during the entire 2 yr survey period (Table 1). Stns SR-1 through SR-7 were occupied by juvenile queen conch, as had been intended in the survey design. There was large variation in density values, however, reflecting the fact that the aggregation has occupied different locations in the same general area over time (Stoner et al. 1996). Although no conch were found in the survey plots at SR-8 and SR-9, we occasionally observed low numbers of juvenile conch at both locations during the surveys. The average density for the $4 \mathrm{CBC}$ stations $(0.57$ conch $\mathrm{m}^{-2}, \mathrm{SD}=0.69$ ) was higher than the average for the 9 SR stations $\left(0.34 \mathrm{~m}^{-2}, \mathrm{SD}=0.50\right)$. Mean density at $\mathrm{CBC}$ 1 ( 1.53 conch $\mathrm{m}^{-2}$ ) was 30 times that found at CBC-4, and none of the 4 stations was ever devoid of conch during the study period.

Table 1 Strombus gigas. Density of live juvenile queen conch at 13 stations near Lee Stocking Island, Exuma Cays, Bahamas, between 1988 and 1990, and density of shell fragments of queen conch sampled in May 1990. Density values are means ( \pm SD) generated from all the surveys from that station

\begin{tabular}{|lcccc|}
\hline Tidal system & Stn & $\begin{array}{c}\text { Conch density } \\
\left(\text { no. } \mathrm{m}^{-2}\right)\end{array}$ & $\begin{array}{c}\text { No. of } \\
\text { surveys }\end{array}$ & $\begin{array}{c}\text { Shell fragment } \\
\text { density (no. m }\end{array}$ \\
\hline Shark Rock & 1 & $0.002 \pm 0.002$ & 7 & $0.13 \pm 0.12$ \\
& 2 & $0.30 \pm 0.08$ & 7 & $0.74 \pm 0.18$ \\
& 3 & $0.33 \pm 0.29$ & 7 & $1.80 \pm 1.01$ \\
& 4 & $1.28 \pm 0.33$ & 7 & $2.24 \pm 0.33$ \\
& 5 & $1.09 \pm 0.31$ & 7 & $1.84 \pm 0.32$ \\
& 6 & $0.05 \pm 0.03$ & 7 & $0.20 \pm 0.09$ \\
& 7 & $0.02 \pm 0.01$ & 7 & $0.12 \pm 0.05$ \\
Children's Bay & 8 & $0 \pm 0$ & 7 & $0.04 \pm 0.02$ \\
Cay & 9 & $0 \pm 0$ & 5 & $0.08 \pm 0.04$ \\
& 1 & $1.53 \pm 0.42$ & 15 & $9.04 \pm 0.41$ \\
& 2 & $0.60 \pm 0.34$ & 5 & $6.79 \pm 1.44$ \\
& 3 & $0.10 \pm 0.03$ & 5 & $2.99 \pm 0.59$ \\
& 4 & $0.05 \pm 0.02$ & 5 & $0.79 \pm 0.17$ \\
\hline
\end{tabular}

Shell fragment densities ranged from a low value of 0.04 fragments $\mathrm{m}^{-2}$ at SR-8, where few live conch were observed, to $>9$ fragments $\mathrm{m}^{-2}$ at $\mathrm{CBC}-1$ where juvenile conch density was highest (Table 1). Regression analysis was performed to test the obvious positive relationship between live conch density and density of shell fragments (Fig. 2). Conch density data were transformed to $\ln$ (conch density +1 ) to provide a normal and homogeneous distribution of residuals. The resulting correlations between conch density during the entire study period and shell fragment density were high. At $\mathrm{CBC}$, nearly $100 \%$ of the variation in fragment density was explained by conch density ( $r=$ $0.998, p=0.002$ ). At $S R, 86 \%$ of the variation was explained $(r=0.928, p<0.001)$, and only 1 station (SR3) fell outside the $95 \%$ confidence intervals. Difference in $y$-intercepts for the 2 nursery areas could not be interpreted by analysis of covariance because the slopes of the regression lines were heterogeneous $\left(F_{1}\right.$ y $=21.52, \mathrm{p}=0.002$ ), but the mean values (Table 1 ) and the plots (Fig. 2) show that densities of shell fragments at $C B C$ were higher than those at SR over the range of juvenile conch densities present. When all stations from both sites were combined in the regression analysis, the correlation coefficient was lower but still significant ( $r=0.709, p=0.007$ ). Using only data from May 1990 (when the fragment data were collected), there was a positive but statistically non-significant relationship between shell fragment density and live conch density at CBC $(r=0.902, p=0.098)_{\text {i }}$ the correlation was low at $S R(r=0.401, p=0.285)$.

Shell decomposition in the field was slow during the first year $\left(\leq 0.18 \mathrm{~g} \mathrm{mo}^{-1}\right)$ with an average loss of $<3 \%$ of shell weight after 12 mo (Table 2). Decomposition accelerated significantly to $\sim 7.5 \% \mathrm{yr}^{-1}$ in Year 2 (CBC: Mann-Whitney $U=5.0, \mathrm{p}=$ 0.003; SR: $U=27.0, \mathrm{p}<0.001$ ) (Fig. 3). The average total loss after 24 to 27 mo was 9 to $10 \%$ at both sites, and $13 \%$ at CBC after 39 mo (Table 2). Decomposition rates (\% total loss) were not different at SR and CBC during both Year $1\left(t_{(35)}=0.336, \mathrm{p}=0.74\right)$ and Year 2 $\left(t_{(19)}=0.104, \mathrm{p}=0.92\right)$.

\section{DISCUSSION}

All carbonate-producing marine organisms, including molluscs, echinoderms, corals, and certain algae, can leave evidence of their presence in the sedimentary record. Preservation of remains, however, is variable and related to the durability and fragility of those remains as well as the depositional environment and other variables (Boucot 

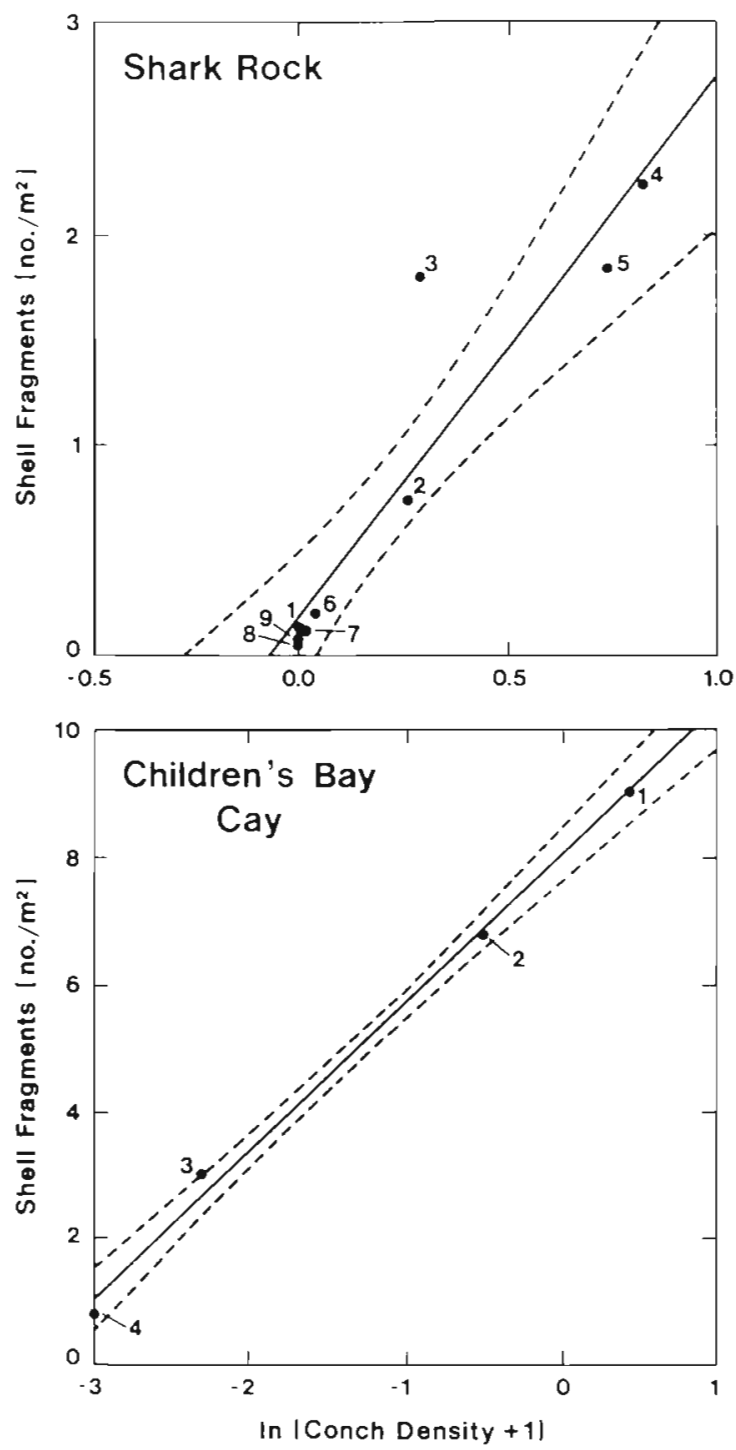

Fig. 2. Strombus gigas. Linear relationship between the density of living juvenile queen conch (1988 to 1990) and the density of conch shell fragments (1990) at 9 stations in the Shark Rock tidal flow field system and at 4 stations in the Children's Bay Cay system. $95 \%$ confidence intervals are shown for the regression lines

1981, Powell et al. 1989). For example, Greenstein (1989) showed that mass mortality of the sea urchin Diadema antillarum in Bonaire in 1983 was not preserved as a recognizable event in the reef sediment because of the rapidity with which their tests were destroyed. Generally, molluscs are more durable and persistent in the sedimentary record. After a 3 yr study, Callender et al. (1994) calculated that a $1 \mathrm{~g}$ mussel shell would lose 3 to $11 \%$ of its total weight each year and that it could last 9 to $30 \mathrm{yr}$, depending upon the deposition site. They predicted much longer survival times for larger, thicker lucinid shells ( 5 to $33 \mathrm{~g}$ ). which showed no significant weight reduction in 3 yr. Driscoll

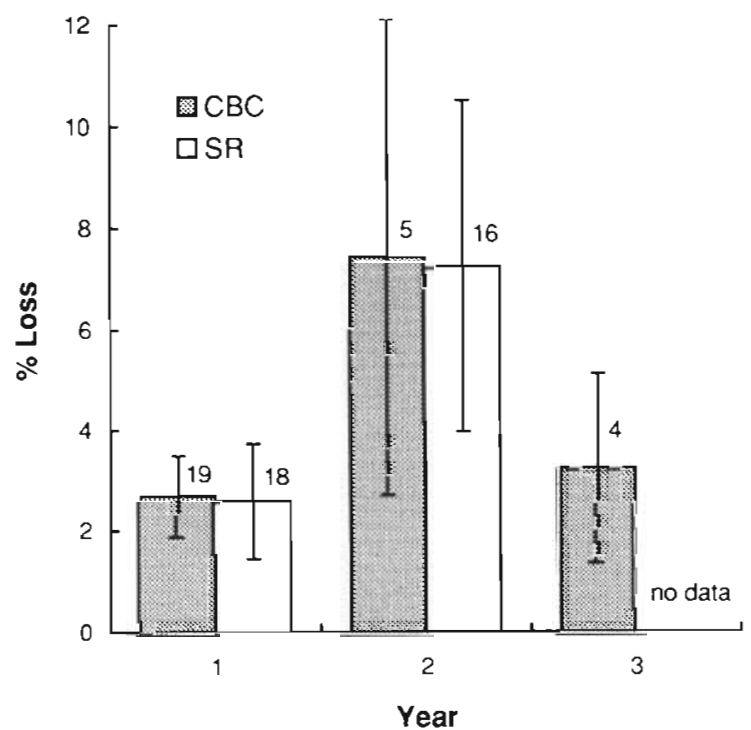

Fig. 3. Strombus gigas. Percentage of total shell weight lost (mean $\pm \mathrm{SD}$ ) at 2 sites near Lee Stocking Island, Bahamas, during 2 years at Shark Rock (SR) and 3 years at Children's Bay Cay (CBC). Numbers of shells recovered for measurement are shown inside each column. Calculations for each year were not cumulative; they were based upon shell weights at the end of the previous year

(1970) observed weight change for shells of 3 bivalve species over 3 yr. He did not remove epifaunal growth, as in our investigation, and shells of 2 species gained 13 to $23 \%$ of their weight after $2 \mathrm{yr}$; shells of the third species, Mercenaria mercenaria, were encrusted very little and lost $4 \%$ of initial weight $(75 \mathrm{~g})$ after $3 \mathrm{yr}$. In comparison, our conch shells $(80 \%$ were $>53 \mathrm{~g}$ initial weight) decreased in weight by 2.6 to $2.7 \%$ during the first year, a little more slowly than weight losses for $1 \mathrm{~g}$ mussel shells, but accelerated to yield $>12 \%$ loss after 39 mo. These results are consistent with the conclusions that dissolution of shells increases with shell thickness and size (Callender et al. 1994).

A host of variables related to the mechanisms of shell reduction could be measured in future studies. These include dissolution, precipitation, abrasion, encrustation, and biological alteration (Powell et al. 1989, Callender et al. 1994, Kowalewski et al. 1994). Regardless of the exact mechanism, at the rate of shell reduction observed in this study, and using the simple calculation used by Callender et al. (1994), a typical shell (50 g) would last $\sim 12$ yr. Therefore, shell fragments on the surface of the sediment in the nurseries should provide a time-averaged distributional record for conch over about a decade.

The relationship between shell fragment density and distribution of live conch was positive and highly significant at both areas examined in this investigation, suggesting the usefulness of the shell record in paleon- 
Table 2. Strombus gigas. Shell material loss (mean \pm SD) over a 2 yr period after deployment at 2 sites near Lee Stocking Island, Bahamas. Losses are calculated in terms of percentage of total weight lost and grams lost by each shell since the beginning of the experiment in mid-May 1992

\begin{tabular}{|c|c|c|c|c|c|}
\hline $\begin{array}{l}\text { Time } \\
\text { (mo) }\end{array}$ & $\begin{array}{l}\text { Date and } \\
\text { site }\end{array}$ & $\begin{array}{l}\text { No. of shelis } \\
\text { measured }\end{array}$ & $\begin{array}{c}\text { Total loss } \\
(\%)\end{array}$ & $\begin{array}{l}\text { Monthly loss } \\
\left(\% \mathrm{mo}^{-1}\right)\end{array}$ & $\begin{array}{l}\text { Rate of loss per } \\
\text { shell }\left(\mathrm{g} \mathrm{mo}^{-1}\right)\end{array}$ \\
\hline \multirow[t]{3}{*}{4} & 11 Sep 92 & & & & \\
\hline & $\mathrm{CBC}$ & 25 & $0.82 \pm 0.39$ & $0.21 \pm 0.10$ & $0.12 \pm 0.06$ \\
\hline & SR & 23 & $1.01 \pm 0.47$ & $0.25 \pm 0.12$ & $0.18 \pm 0.06$ \\
\hline \multirow[t]{3}{*}{12} & 15 May 93 & & & & \\
\hline & $\mathrm{CBC}$ & 19 & $2.70 \pm 0.79$ & $0.23 \pm 0.07$ & $0.15 \pm 0.03$ \\
\hline & $\mathrm{SR}$ & 18 & $2.50 \pm 1.15$ & $0.22 \pm 0.09$ & $0.15 \pm 0.06$ \\
\hline \multirow[t]{2}{*}{24} & 27 May 94 & & & & \\
\hline & $\mathrm{SR}$ & 19 & $9.80 \pm 3.64$ & $0.41 \pm 0.15$ & $0.27 \pm 0.06$ \\
\hline \multirow[t]{2}{*}{27} & 26 Aug 94 & & & & \\
\hline & $\mathrm{CBC}$ & 6 & $9.36 \pm 4.41$ & $0.35 \pm 0.16$ & $0.21 \pm 0.09$ \\
\hline \multirow[t]{2}{*}{39} & 30 Aug 95 & & & & \\
\hline & $\mathrm{CBC}$ & 4 & $12.57 \pm 7.01$ & $0.32 \pm 0.18$ & $0.21 \pm 0.01$ \\
\hline
\end{tabular}

probably limits hermit crab populations (Vance 1972, Spight 1977), it can be argued that hermit crabs are unlikely to disperse far from a productive shell source, such as a juvenile queen conch aggregation. Hermit crabs may, in fact, transport shells from the exact site of mortality, but it is unlikely that this form of dispersion influences shell distribution on the scale of $100 \mathrm{~s}$ to $1000 \mathrm{~s}$ of meters explored in this study. Moreover, shell fragments were indeed distributed like the 2 yr record of live conch.

The most likely explanation for higher shell abundance at $\mathrm{CBC}$ is a difference in long-term population density. Surveys spanning the period from 1988 to 1995 (Stoner et al. 1996 , unpubl. data) show that the CBC

tological and ecological interpretation. However, shell concentrations relative to live conch densities were higher at CBC than at SR. There are several possible explanations for this observation: differences in shell deterioration, transport, deposition, and burial, differences in conch mortality, and differences in long-term population density. Higher concentrations at $\mathrm{CBC}$ are not explained by shell deterioration because weight losses were similar at the 2 sites. They are unlikely to be explained by differences in the depositional environment because the 2 areas are adjacent in the Exuma Cay island chain and have similar physical oceanographic characteristics, sediment grain-size distribution, and sediment organic content (Stoner \& Waite 1990, Stoner et al. 1994). Differential mortality is also unlikely: experiments conducted in 1992 showed that juvenile conch held on tethers in the 2 areas were killed at approximately equal rates (Ray \& Stoner 1995).

Physical transport and spatial variation in accumulation of shells was not significant for molluscan species observed in California (USA) lagoons (Warme 1969, 1971, Peterson 1976), and shell transport was probably not a major problem on the scale of this investigation. Conch shells are heavy and have long apical spines. These features reduce their tendency to be transported by physical energy, particularly in the low-energy, 3 to $4 \mathrm{~m}$ deep seagrass habitats where the shells are produced and deposited. The primary source of transport was probably hermit crabs that frequently inhabit conch shells at the 2 study sites. Hermit crabs cause numerous anomalies in gastropod shell distribution, and their potential to confuse interpretation of distribution from the fossil record is well studied (Walker 1989). However, because availability of suitable shells aggregation maintained its peripheries more consistently than the SR aggregation, and was typically larger in area and more densely populated. Also, in 1987, 1 high-density mass migration of juvenile conch at $\mathrm{CBC}$ contained over 210000 individuals in densities as high as 300 conch $\mathrm{m}^{-2}$ (Stoner et al. 1988). This aggregation persisted for $5 \mathrm{mo}$, and it is likely that the very strong 1986 year-class producing it contributed substantially to the shell material at the site.

Establishment of positive relationships between living and fossil assemblages is critical for understanding temporal and spatial changes in abundance and distribution. Several authors have reported positive correlations between abundance, distribution, and diversity of skeletal remains in the sedimentary record and living populations of hard-shelled invertebrates such as molluscs (Johnson 1965, Warme 1969, 1971, Kranz 1974, Levinton \& Bambach 1975, Peterson 1976, 1977), crinoids (Meyer \& Meyer 1986), and urchins (Greenstein 1989), and these remains are commonly interpreted by paleontologists. It has been pointed out (Peterson 1976, 1977), however, that short-term asynchronous temporal variation of species in a community can result in overestimates of species richness for any one time because of the time-averaging qualities of the sedimentary record. Similarly, the distribution of a species as shown in the sedimentary record may be larger than the distribution at any one time, but this spatialtime-averaging has certain benefits relevant to the ecological time scale.

Queen conch (Ray \& Stoner 1994, Stoner \& Lally 1994, Stoner et al. 1996), other motile molluscs (Catterall \& Poiner 1983, Stokesbury \& Himmelman 1993), and echinoderms (Lawrence 1975, Scheibling 1985) move about in aggregations over much larger ranges 
than observed at any single point in time. Our surficial shell fragment records did not correlate well with living conch distribution on the date of shell surveys, but had a nearly perfect fit with the multi-season, multiyear distributional pattern examined in this study. Therefore, a single survey of surficial shell fragment density may provide a more accurate map of the actual habitat use by this species than any single live animal survey. Similar conclusions were drawn by Warme et al. (1976) and Kidwell \& Bosence (1991).

Shell remains in the sedimentary record could prove useful in fisheries management. For example, with an understanding of the taphonomic processes, it should be possible to detect shrinkage of stocks or habitat use over the scale of decades, and to identify important nursery areas for protection or stock enhancement. Also, release of hatchery-reared queen conch has long been proposed as a means for rehabilitating severely overfished populations in the Caribbean (Cresswell 1994). However, the suitability of an area for nursery habitat is difficult to predict, and stock enhancement efforts have frequently suffered from releases made in suboptimal habitats (Stoner 1994). An examination of the historical distribution pattern of queen conch in the sedimentary record may provide a useful tool in predicting suitable release sites and the most important sites for conservation and stock rehabilitation.

The ecological and fisheries applications depend, of course, on the stability of the physical and biological environment, and predictive capabilities will probably decline with the age of the record. For example, increased levels of pollution or siltation might preclude establishment of juvenile conch where they were once present in abundance. On the other hand, indications of disturbance could be derived from the shell record in light of information on environmental factors.

There are numerous limitations in using skeletal and shell remains to interpret patterns of biological distribution and abundance. However, close correlation between queen conch shell fragments on the surface of the sediment and density of living nursery aggregations observed in this study provides empirical evidence supporting the value of shell fragment analysis in both paleontological and ecological context.

Acknowledgements. We thank P. Yoshioka, who suggested collecting shell fragments in conch nurseries and who made the first measurements near Lee Stocking Island. M. Davis, R. Gomez, S. O'Connell, V Sandt, J. Waite, B. Yoshioka, and numerous other persons assisted in field surveys during this study. Funding was provided by the National Undersea Research Program of NOAA. (U.S. Department of Commerce). R. F. Dill, B. Greenstein, C. H. Peterson, E. N. Powell, and E. A. Shinn provided helpful comments on our taphonomic and geological interpretations.

\section{LITERATURE CITED}

Aoyama S (1989) The Mutsu Bay scallop fisheries: scallop culture, stock enhancement, and resource management. In: Caddy JF (ed) Marine invertebrate fisheries: their assessment and management. Wiley, New York, p $525-539$

Berg CJ Jr, Olsen DA (1989) Conservation and management of queen conch (Strombus gigas) fisheries in the Caribbean. In: Caddy JF (ed) Marine invertebrate fisheries: their assessment and management. Wiley, New York, p 421-442

Boucot AJ (1981) Principles of benthic marine paleoecology. Academic, New York

Brownell WN, Stevely JM (1981) The biology, fisheries, and management of the queen conch, Strombus gigas. Mar Fish Rev 43:1-12

Caddy JF (1979) Long-term trends and evidence for production cycles in the Bay of Fundy scallop fishery. Rapp P-V Réun Cons Int Explor Mer 175:97-108

Callender WR, Powell EN, Staff GM (1994) Taphonomic rates of molluscan shells placed in autochthonous assemblages on the Louisiana continental slope. Palaios 9:60-73

Catterall CP, Poiner IR (1983) Age- and sex-dependent patterns of aggregation in the tropical gastropod Strombus Iuhuanus. Mar Biol 77:171-182

Clarkson ENK (1993) Invertebrate palaeontology and evolution, 3rd edn. Chapman \& Hall, London

Cresswell RL (1994) A historical overview of queen conch mariculture. In: Appeldoorn RS, Rodriquez B (eds) Queen conch biology, fisheries, and mariculture. Fundacion Cientifica Los Roques, Caracas, p 223-230

Davis M. Stoner AW (1994) Trophic cues induce metamorphosis of queen conch larvae (Strombus gigas Linnaeus). J Exp Mar Biol Ecol 180:83-102

Dickie LM (1955) Fluctuations in abundance of the giant scallop, Placopecten magellanicus (Gmelin), in the Digby area of the Bay of Fundy. J Fish Res Bd Can 12:797-857

Driscoll EG (1970) Selective bivalve shell destruction in marine environments - a field study. J Sedim Petrol 40:898-905

Glazer RA, Berg CJ Jr (1994) Current and future queen conch, Strombus gigas, research in Florida. In: Appeldoorn RS, Rodriquez B (eds) Queen conch biology, fisheries and mariculture. Fundacion Científica Los Roques, Caracas, p 79-95

Greenstein BJ (1989) Mass mortality of the West Indian echinoid Diadema antillarum (Echinodermata: Echinoidea): a natural experiment in taphonomy. Palaios 4:487-492

Greenstein BJ (1992) Taphonomic bias and the evolutionary history of the family Cidaridae (Echinodermata: Echinoidea). Paleobiology 18:50-79

Hallam A. (1984) Distribution of fossil marine invertebrates in relation to climate. In: Brenchley $P$ (ed) Fossils and climate. Wiley, Chichester, p 107-125

Henderson RA, Walbran PD (1992) Interpretation of the fossil record of Acanthaster planci from the Great Barrier Reef: a reply to criticism. Coral Reefs 11:95-101

Johnson RG (1965) Pelecypod death assemblages in Tomales Bay, California. J Paleontol 39:80-85

Keegan WF (1984) Pattern and process in Strombus gigas tool replication. J New World Archaeol 6:15-25

Keegan WF (1986) The ecology of Lucayan Arawak fishing practices. Am Antiq 51:816-825

Keegan Wr (1992) I he people who discovered Coiumius: ine prehistory of the Bahamas. Univ Press Florida, Gainesville

Keesing JK, Bradbury RH, DeVantier LM, Riddle MJ, De'ath $G$ (1992) Geological evidence for recurring outbreaks of 
the crown-of-thorns starfish: a reassessment from an ecological perspective. Coral Reefs 11:79-85

Kidwell SM (1991) The stratigraphy of shell concentrations. In: Allison PA, Briggs DEG (eds) Taphonomy: releasing the data locked in the fossil record. Plenum, New York, $p$ $211-290$

Kidwell SM, Bosence DWJ (1991) Taphonomy and time-averaging of marine shelly faunas. In: Allison PA, Briggs DEG. (eds) Taphonomy: releasing the data locked in the fossil record. Plenum, New York, p 116-209

Kowalewski M. Flessa KW. Aggen JA (1994) Taphofacies analysis of recent shelly cheniers (beach ridges), northeastern Baja California, Mexico. Facies 31:209-242

Kranz PM (1974) The anastrophic burial of bivalves and its paleoecological significance. J Geol 82:237-265

Lawrence JM (1975) On the relationships between marine plants and sea urchins. Oceanogr Mar Biol A Rev 13 $213-286$

Levinton JS, Bambach RK (1975) A comparative study of Silurian and recent deposit-feeding bivalve communities Paleobiology 1:97-124

Meehan B (1982) Shell bed to shell midden. Australian Institute of Aboriginal Studies, Globe, Melbourne

Meyer DL, Meyer KB (1986) Biostratinomy of recent crinoids (Echinodermata) at Lizard Island, Great Barrier Reef, Australia. Palaois 1:294-302

Pandolfi JM (1992) A palaeobiological examination of the geological evidence for recurring outbreaks of the crownof-thorns starfish, Acanthaster planci (L.). Coral Reefs 11 : $87-93$

Peterson CH (1975) Stability of species and of community for the benthos of two lagoons. Ecology 56:958-965

Peterson CH (1976) Relative abundance of living and dead molluscs in two California lagoons. Lethaeia 9:137-148

Peterson $\mathrm{CH}$ (1.977) The paleoecological signifıcance of undetected short-term temporal variability. J Paleontol 51 . 976-981

Powell EN, Stagg GM, Davies DJ, Callender WR (1989) Macrobenthic death assemblages in modern marine environments: formation, interpretation, and application. Crit Rev Aquat Sci 1:555-589

Randall JE (1964) Contributions to the biology of the queen conch, Strombus gigas. Bull Mar Sci 14:246-295

Ray M. Stoner AW (1994) Experimental analysis of growth and survivorship in a marine gastropod aggregation: balancing growth with safety in numbers. Mar Ecol Prog Ser 105:47-59

Ray M, Stoner AW (1995) Predation on a tropical spinose gastropod: the role of shelJ morphology. J Exp Mar Biol Ecol $187: 207-222$

Ray M. Stoner AW, O'Connell SM (1994) Size-specific predation of juvenile queen conch, Strombus gigas: implications for stock enhancement. Aquaculture 128:79-88

Scheiblung RE (1985) Directional movement in a sea star (Oreaster reticularus): adaptive significance and ecological consequences. In: Rankin MA (ed) Migration: mechanisms and adaptive significance. Contr Mar Sci Univ Texas (Suppl) 27:244-256

Shawcross W (1967) An investigation of prehistoric diet and economy on a coastal site at Galatea Bay, New Zealand. Proc Palaeontol Soc 33:107-133

Spight T (1977) Availability and use of shells by intertidal hermit crabs. Biol Bull 1.53:120-133

Stokesbury KDE, Himmelman JH (1993) Spatial distribution of the giant scallop Placopecten magellanicus in unharvested beds in the Baie des Chaleurs, Quebec. Mar Ecol Prog Ser 96:159-168

This article was presented by C. H. Peterson (Senior Editorial Advisor), Morehead City, North Carolina, USA
Stoner AW (1994) Significance of habitat and stock pre-testing for enhancement of natural fisheries: experimental analyses with queen conch. J World Aquacult Soc 25: $155-165$

Stoner AW, Davis M (1997) Abundance and distribution of queen conch veligers (Strombus gigas Linne) in the central Bahamas: 1. Horizontal patterns in relation to reproductive and nursery grounds. Bull Mar Sci 60:in press

Stoner AW, Hanisak MD, Smith NP, Armstrong RA (1994) Large-scale distribution of queen conch nursery habitats: implications for stock enhancement. In: Appeldoorn RS, Rodriquez B (eds) Queen conch blology, fisherles and mariculture. Fundacion Cientifica Los Roques, Caracas, p $169-189$

Stoner AW, Lally J (1994) High-density aggregation in queen conch, Strombus gigas: formation, patterns, and ecological significance. Mar Ecol Prog Ser 106:73-84

Stoner AW, Lipcius RN, Marshall LS Jr, Bardales AT (1988) Synchronous emergence and mass migration in juvenile queen conch. Mar Ecol Prog Ser 49:51-55

Stoner AW, Pitts PA, Armstrong RA (1996) The interaction of physical and biological factors in the large-scale distribution of juvenile queen conch populations in seagrass meadows. Bull Mar Sci 58:217-233

Stoner AW, Ray M (1993) Aggregation dynamics in juvenile queen conch (Strombus gigas): population structure, mortality, growth, and migration. Mar Biol 116:571-582

Stoner AW, Schwarte KC (1994) Queen conch reproductive stocks in the central Bahamas: distribution and probable sources. Fish Bull US 92:171-179

Stoner AW, Waite JM (1990) Distribution and behavior of queen conch, Strombus gigas, relative to seagrass standing crop. Fish Bull US 88:573-585

Tegner M (1989) The California abalone fishery: production, ecological interactions, and prospects for the future. In: Caddy JF (ed) Marine invertebrate fisheries: their assessment and management. Wiley, New York, p 401-420

Valentine JW (1973) Evolutionary paleoecology of the marine biosphere. Prentice-Hall, Englewood Cliffs, NJ

Vance R (1972) The role of shell adequacy in behavioral interactions involving hermit crabs. Ecology 53:1075-1083

Van Valen L (1964) Relative abundance of species in some fossil mammal faunas. Am Nat 98:109-11.6

Vermeij GJ (1987) Evolution and escalation: an ecological history of Life. Princeton Univ Press, Princeton, NJ

Walker KR, Bambach RK (1971) The signuficance of fossil assemblages from fine-grained sediments: time-averaged communities. Geol Soc Am Abs with Programs 1971, 3: $783-784$

Walker SE (1989) Hermit crabs as taphonomic agents. Palaıs $4: 439-452$

Warme JE (1969) Live and dead molluses in a coastal lagoon. J Paleontol 43:141-150

Warme JE (1971) Paleoecological aspects of a modern coastal lagoon. Univ Calif Publ Geol Sci 87:1-131

Warme JE, Ekdale AA, Ekdale SF. Peterson C.H (1976) Raw material of the fossil record. In: Scott RW, West RR (eds) Structure and classification of paleocommunities. Dowden, Hutchinson \& Ross, Stroudsburg, PA, p 143-169

Wicklund RI, Hepp LJ, Wenz GA (1991) Preliminary studies on the early life history of the queen conch, Strombus gigas, in the Exuma Cays, Bahamas. Proc Gulf Caribb Fish Inst 40:283-298

Woodin SA (1983) Biotic interactions in recent massive sedimentary environments. In: Tevesz MJS, McCall PL (eds) Biotic interactions in recent and fossil benthic communities. Plenum, New York, p 3-38 